\title{
IMPROVING STUDENTS' READING COMPREHENSION THROUGH SQ3R (SURVEY, QUESTION, READ, RECITE AND REVIEW) TECHNIQUE
}

\author{
Gian Reka Anjuni ${ }^{1}$, Roby Cahyadi ${ }^{2}$ \\ ${ }^{1}$ IKIP SILIWANGI \\ ${ }^{2}$ IKIP SILIWANGI \\ 1giojaya726@gmail.com, ${ }^{2}$ roby.radiance0007@gmail.com,
}

\begin{abstract}
This research entitled "Improving Students' Reading Comprehension Through SQ3R Technique". This research aims at finding out the use of SQ3R strategy in improving students' reading comprehension. The population of this research is students of SMA Negeri 1 Cipongkor including eleventh grade of IPS class and IPA class. The number of population is 60 students. The sample of this research is only one class that is IPS class consists 30 students. The quantitative research method is used in this research, and specifically the one group pre-test post-test design as research design. The instrument of this researches is pretest and posttest and the writers also use t-test formula for collecting data. The result of the research shows that tobs is 2.42, the ttable with degrees of freedom (df) 29 and level of significance at 0.05 was 1,69. Based on the data, the t-test result was 2.42 , it was higher that t-table $(2.42>1.69)$. It means the alternative hypothesis was accepted. According to the data analysis which is collected, it can be concluded that the test is reliable. And the research showed that teaching students' reading comprehension using SQ3R technique is very useful. That is why, the SQ3R strategy is suitable in improving students' reading comprehension.
\end{abstract}

Keywords: Reading, Reading Comprehension, SQ3R Strategy

\section{INTRODUCTION}

According to Dreyer (1998, as cited in Apsari, 2016 ), reading is the most important skill for second language learners in academic contexts. Furthermore, Harmer (2007, in Apsari, 2014) argues that getting students to read English texts is an important part of the English teacher's job because of four reasons. First, many students want and need to be able to read English texts for present study, for furtherstudy, for future career or simply for pleasure. Second, reading is very useful for language acquisition. Third, reading texts provide good models for English writing concerning

construction of phrases, sentences, paragraph, and whole texts. Finally, good reading texts can introduce interesting topics, stimulate discussion, excite creative responses, and provide the springboard for well-rounded, fascinating lessons.

Deborah \& Santi (2015) state "that reading comprehension as a process in which the reader the reader constructs meaning from text-based information." They also argues that during this process, the reader creates a mental representation of the meaning of the text by using features of the text and the reader's knowledge of the world. 
Cahyadi-1, Anjuni-2, Improving Students' Reading Comprehension Through Sq3r (Survey,

Question, Read, Recite And Review) Technique

By reading, we get many benefits such as we can gain new knowledge, information and increase our vocabularies especially in English language. As one of abilities in English, reading has several types that can be provided for students especially for reader. Patel (2008) states that reading is a complex skill involving a number of simultaneous operation. Reading has been divided into some parts:

1. Reading aloud

2. Silent Reading

3. Extensive reading

For improving students' reading comprehension, the suitable strategy or method is needed to make it more reliable and relevant. Because, there are still many problems in learning English language especially in reading skill. The problems may occur for students are they lack of vocabularies, students cannot comprehend text well and they cannot understand the content of the text either. Therefore, the teacher should provide students with the reliable and interesting technique to improve their comprehension. One of strategies that can be provided is SQ3R technique. SQ3R is introduced by Robinson (1970). He states that "SQ3R is a reading strategy designed to help students improve their comprehension, memory, and efficiency in reading." Furthermore, (Brandon \& Brandon, 2014) define SQ3R as a comprehensive reading system that will give you both perspective and understanding.

According to Davis \& Davey (2014), "SQ3R is a reading comprehension method that can help students build a framework to understand a text. This method can be helpful to students because it helps readers develop a mental framework in which to fit what they read."

The SQ3R reading/study system provides students with a great deal of repetition, breaks the task of reading into smaller segments, and has a built-in comprehension-monitoring system.

1. One of the greatest advantages of using the SQ3R reading/study system is that it allows for a great deal of repetition of the important information in the chapter.

2. Focus on smaller segments of material. Another advantage of SQ3R is its focus on smaller unit of material.

3. Built-in comprehension-monitoring system. Another advantages of SQ3R is that it has a built in comprehension monitoring system.

SQ3R is very useful to memorize and understanding the content of the text. It also can be useful for students to gain message from the text as well. To make this strategy more reliable and efficient, it should be provided by using suitable procedurals. These procedurals are used in order the strategy can be more useful for improving students' reading comprehension.

\section{METHOD}

The research design of this research was conducted by using quantitative research design, more specifically pre-test post-test design as research method. According to Leedy (1993) quantitative research design is research methods dealing with numbers and anything that is measurable in a systematic way of investigation of phenomena and their relationships. It is used to answer questions on relationships within measurable variables with an intention to explain, predict and control a phenomena. The instruments of the research to collect the data was pretest and post-test. 
The design of one group pre-test post-test can be seen as follows:

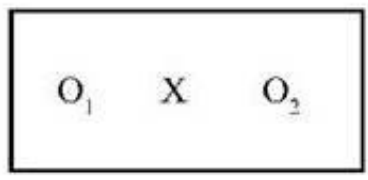

Figure 1. Design of one group pre-test post-test

To develop the data, the quantitative research method was applied by writer. The research subject of the research was students of SMAN 1 Cipongkor that was located Jl. PLTA Saguling Desa Sarinagen Kecamatan Cipongkor-Bandung Barat. The research population was the eleventh grade students of SMAN 1 Cipongkor consist two class, IPA and IPS class with the number of population was 60 students. Johnson in (Kaswan \& Suprijadi, 2016a) defines that population as "the entire group of entities or persons to which the result of a study is intended to apply" Specifically, the research sample was only one class, which was IPS class that consisted 30 students.

To make the research become proven accurately, the writer use several data collection technique in order this research become more accurate and reliable.

The instrument of this researches was pretest and posttest and the writers also use t-test formula for collecting data. The writers used multiple choice that contained 30 items for the test.

- Pre-test was conducted to measure how far students' reading comprehension ability before the writer conducted the treatment through SQ3R technique.

- Treatment was applied after the pre-test. The treatment in this research was used by using SQ3R technique that was provided for students of SMA Negeri 1 Cipongkor including XI IPS 1

- Post-test was conducted after the treatment. Post-test was applied to compare the result between pre-test and post-test and to collect the data from the research.

To gain the accurate and reliable result of data analysis, writer used several formulas in order the research become well-proven, the formulas that was used in this research were:

\section{Mean Score}

According to Kaswan \& Suprijadi (2016b), "the mean is sometimes called the arithmetic mean to distinguish it from other forms of mean such as the harmonic mean or geometric mean." The formula as follows:

$$
x=\frac{\sum x}{n}
$$

\section{Standard Deviation}

Standard deviation is the most widely used measure of variability of a set of data in inferential statistical procedures (Kaswan \& Suprijadi, 2016b). The formula of standard deviation is:

$$
\mathrm{SD}=\sqrt{\frac{\Sigma D^{2}-\left(\frac{1}{n}\right)(\Sigma D)^{2}}{n-1}}
$$


Cahyadi-1, Anjuni-2, Improving Students' Reading Comprehension Through Sq3r (Survey,

Question, Read, Recite And Review) Technique

\section{Degree of Freedom}

Degree of freedom is applied to compare between the obtained $t_{\text {obs }}$ with the table entry for relevant degree of freedom and level significant. The formula is:

$$
\mathrm{df}=\mathrm{n}-1
$$

\section{T-test Formula}

According to (Kaswan \& Suprijadi, 2016b) state that 't-test or students' test is a parametric test which is used to discover whether here are statistically significant differences between the means of two group." The formula is:

$$
\mathrm{t}=\frac{\bar{x}_{1}-\bar{x}_{2}}{S D}
$$

\section{RESULTS AND DISCUSSION}

\section{Results}

The result of the research was taken from pre-test and post-test were conducted by writer. Pretest was conducted before the treatment and post-test was done after the treatment. The result of pre-test and post-test of student as follows:

Table 1. The Result of Pre-Test and Post-Test

\begin{tabular}{cccccc}
\hline \multirow{2}{*}{ No } & \multirow{2}{*}{ Name } & \multicolumn{4}{c}{ Score } \\
\cline { 3 - 6 } & & Pre-test & Post-test & $\boldsymbol{\Sigma} \boldsymbol{D}$ & $\boldsymbol{\Sigma D}^{\mathbf{2}}$ \\
\hline 1 & Student 1 & 63 & 80 & 17 & 289 \\
\hline 2 & Student 2 & 53 & 63 & 10 & 100 \\
\hline 3 & Student 3 & 63 & 70 & 7 & 49 \\
\hline 4 & Student 4 & 53 & 70 & 17 & 289 \\
\hline 5 & Student 5 & 60 & 80 & 20 & 400 \\
\hline 6 & Student 6 & 60 & 80 & 20 & 400 \\
\hline 7 & Student 7 & 66 & 83 & 17 & 289 \\
\hline 8 & Student 8 & 33 & 60 & 27 & 729 \\
\hline 9 & Student 9 & 66 & 70 & 4 & 16 \\
\hline 10 & Student 10 & 83 & 96 & 13 & 169 \\
\hline 11 & Student 11 & 63 & 83 & 20 & 400 \\
\hline 12 & Student 12 & 66 & 76 & 10 & 100 \\
\hline 13 & Student 13 & 66 & 76 & 10 & 100 \\
\hline 14 & Student 14 & 53 & 73 & 20 & 400 \\
\hline 15 & Student 15 & 56 & 76 & 20 & 400 \\
\hline 16 & Student 16 & 53 & 70 & 17 & 289 \\
\hline 17 & Student 17 & 53 & 76 & 23 & 529 \\
\hline 18 & Student 18 & 60 & 80 & 20 & 400 \\
\hline 19 & Student 19 & 53 & 76 & 23 & 529 \\
\hline 20 & Student 20 & 96 & 100 & 4 & 16 \\
\hline 21 & Student 21 & 43 & 63 & 20 & 400 \\
\hline 22 & Student 22 & 76 & 90 & 14 & 196 \\
\hline
\end{tabular}




\begin{tabular}{clcccc}
\hline 23 & Student 23 & 80 & 96 & 16 & 256 \\
\hline 24 & Student 24 & 80 & 100 & 20 & 400 \\
\hline 25 & Student 25 & 46 & 60 & 14 & 196 \\
\hline 26 & Student 26 & 33 & 56 & 20 & 400 \\
\hline 27 & Student 27 & 53 & 60 & 7 & 49 \\
\hline 28 & Student 28 & 76 & 80 & 4 & 16 \\
\hline 29 & Student 29 & 73 & 80 & 7 & 49 \\
\hline 30 & Student 30 & 70 & 80 & 10 & 100 \\
\hline & Total & $\mathbf{1 8 4 9}$ & $\mathbf{2 3 0 3}$ & $\mathbf{4 5 1}$ & $\mathbf{7 9 5 5}$ \\
\hline Average & 61.63 & 76.77 & 15.03 & 265.17 \\
\hline
\end{tabular}

From the result above, the writer analyzed the collected data using the formulas, as follows:

- Mean Score of Pre-test

$$
x=61.63
$$

- Mean Score of Post-Test

$$
x=76.77
$$

\section{- Standard Deviation Score of Pre-test}

$$
\begin{aligned}
& \mathrm{SD}=\sqrt{\frac{\Sigma D^{2}-\left(\frac{1}{n}\right)(\Sigma D)^{2}}{n-1}} \\
& \mathrm{SD}=\sqrt{\frac{7955-\left(\frac{1}{30}\right)(451)^{2}}{29}} \\
& \mathrm{SD}=\sqrt{\frac{1175}{29}} \\
& \mathrm{SD}=\sqrt{40.51} \\
& \mathrm{SD}=6.36
\end{aligned}
$$

- T-Test

$$
\begin{aligned}
& \mathrm{t}=\frac{\bar{x}_{1}-\bar{x}_{2}}{S D} \\
& \mathrm{t}=\frac{61.36-76.77}{6.36} \\
& \mathrm{t}=2.42^{6.36}
\end{aligned}
$$

\section{Discussion}

Based on the result, the value of t-table with degree of freedom (df) 29 and the level of significance at 0.05 was 1.69 . The t-test result was 2.42 , it was higher that t-table $(2.42>1.69)$. It means the alternative hypothesis was accepted and null hypothesis was rejected. 
Cahyadi-1, Anjuni-2, Improving Students' Reading Comprehension Through Sq3r (Survey,

Question, Read, Recite And Review) Technique

\section{CONCLUSION}

Based on the analyzed data, it result proved that SQ3R technique was efficient and reliable. It can be proven by the value of t-table with degree of freedom (df) 29 and the level of significance at 0.05 was 1.69 . The t-test result was 2.42 , it was higher that t-table $(2.42>1.69)$. It means the alternative hypothesis was accepted and null hypothesis was rejected. Therefore, SQ3R can be used as one of strategy for teacher to provide learning more efficient and reliable.

\section{ACKNOWLEDGMENTS}

First of all the writers would like to express thanks to The Head Master of SMA Negeri 01 Cipongkor, for his permission to conduct research. The second is the writers would like to express thanks to our lecturer for all advices, guidance, and corrections during the completion of this paper. The third is the writers also thank the audiences at template in Professional Journal of English Education (PROJECT), and IKIP Siliwangi supported received for the work.

\section{REFERENCES}

Apsari, Y. (2014). The use of authentic materials in teaching reading comprehension. ELTIN JOURNAL, Journal of English Language Teaching in Indonesia, 2(2).

Apsari, Y. (2016). CLOZE PASSAGE IN IMPROVING STUDENTS'READING COMPREHENSION. ELTIN JOURNAL, Journal of English Language Teaching in Indonesia, 4(2), 53-62.

Brandon \& Brandon (2014) At a Glance: Writing Essays and Beyond. USA: Cengage Learning. Davis \& Davey (2014) Tech Tools for Improving Student Literacy. New York: Routledge.

Deborah \& Santi (2015) Improving Reading Comprehension of Middle and High School Students. New York: Springer.

Kaswan \& Suprijadi (2016a) Metode dan teknik penulisan karya ilmiah. Edisi 2 (2015) Revisi 1 (2016). Bandung: STKIP SILIW ANGI Press.

Kaswan \& Suprijadi (2016b) Research in English Education. Bandung: Putra Praktisi.

Leedy, P. D. (1993) Practical Research: Planning and Design. New York: Mackmillan Publishing Company.

Patel (2008) English Language Teaching. Jaipur: Sunrise Publisher \& Distributors.

Robinson, F. P. (1970) SQ3R: Effective study (4th ed.). New York: Harper \& Row. 